\title{
Da contradição à colaboração: crítica da alienação da socialidade capitalista
}

Raphael Lana Seabra

Curso: Mestrado em Sociologia

Data da defesa: 14 de março de 2008

Orientador: Prof. Dr. Sadi Dal Rosso

\section{Resumo}

Neste trabalho buscamos compreender o aprofundamento da experiência da alienação da classe trabalhadora na contemporaneidade.

No primeiro momento, realizamos o resgate dos fundamentos da ontologia social marxiana e lukacsiana e apresentamos a especificidade do ser social: o trabalho. De tal modo, o trabalho não é reconstituído somente como antagonista do capital, mas como agente soberano criativo do processo contínuo de humanização do ser social.

No segundo momento, com base nos Manuscritos econômicofilosóficos, analisamos o conceito-chave de alienação de modo a ressaltar não só as possibilidades de superação desse fenômeno, mas também os quatro aspectos que o fundamentam: o homem alienado da natureza, o homem alienado de si mesmo, o homem alienado do gênero e o homem alienado do outro homem. Também procuramos avançar na compreensão de sua substancialidade através do conceito de personificações do trabalho e do capital, não no sentido da identidade sujeito-objeto, mas no da internalização das necessidades 
de valorização do capital como necessidades subjetivas.

No terceiro momento, avaliamos as condições históricas que compõem a dinâmica do capital e as peculiaridades que compõem seu sistema orgânico, assim como os traços que distinguem suas diversas formas. Perante as transformações mais recentes na esfera de acumulação do capital, desde sua crise estrutural até as diversas experiências produtivas, apontamos o modelo produtivo toyotista como "momento predominante" da produção global de mercadorias.

No quarto momento, centralizamos nossas atenções em três categorias profissionais distintas - bancários, teleoperadores e operadores de caixa em supermercados - no intuito de verificar a continuidade e o aprofundamento da experiência da alienação no cotidiano do trabalho.

A leitura de nossa pesquisa de campo revelou que, apesar do recurso a práticas mais "humanizadoras" e até mesmo ao "rebatismo" da classe trabalhadora em colaboradores, isso não representa de fato um avanço no fim do fenômeno da alienação e muito menos na extinção das contradições clássicas entre capital e trabalho.

Palavras-chaves: ontologia, trabalho, socialidade, alienação, capitalismo, relações de trabalho. 